\title{
Invictus Poem by William Ernest and Its Contribution to the Social Environment during Pandemic: Study of Sociology Literature
}

\author{
Novia Permata Silviandari ${ }^{1^{*}}$, and $M$. Suryadi ${ }^{2}$ \\ ${ }^{1}$ Master of Literature Department of Indonesian literature, Faculty of Humanities, Diponegoro \\ University, Semarang - Indonesia \\ ${ }^{2}$ Master of Literature Department of Indonesian literature, Faculty of Humanities, Diponegoro \\ University, Semarang - Indonesia
}

\begin{abstract}
The Covid-19 pandemic brings a heartbreaking story for all people in the whole world. This pandemic situation emerged in early 2020 and caused a significant impact on human life. In living a new normal life during a pandemic, people must have a tough life and a high spirit of life. In this study, the researcher using the Mimesis theory in the poem Invictus by William Ernest. The statement of this research is to find out the impact and the role of William Ernest's Invictus poem on the sociological conditions of society during the pandemic. The data analysis method that is used is the descriptive method. This poem will be analyzed based on Mimesis theory by Plato and Aristoteles. The results show that William Ernest's poem Invictus contributes and relates to giving power of life to the social environment during the pandemic.
\end{abstract}

\section{INTRODUCTION}

According to International Journal written by S.M Faisal Arafat [2], the poem Invictus is a famous poem written by William Ernest. The poem is written in the fourth chapter of Life and Death in book collections of poetry entitled Book of Verses. This poem was written in 1875 and published in a book in 1888. Invictus is taken from Latin, which means "incomparable" [2].

William Ernest, in his poetry, interpreted that victory in life happens when we decide to keep trying to be strong while going through challenging situations in life [1]. The writing background from this poem is William's remarkable determination to get through challenging situations in his life due to tuberculosis since his childhood. That disease slowly attacked his body and made him lose his leg when he was seventeen [2]. The story of William Ernest's struggle in dealing with difficult situations in his life is written in words that can invite the reader soul to feel the toughness and determination. So the story of William Ernest's life makes this poem interesting to analyze because it provides a positive reflection to the reader.

*Corresponding author: noviasilviandari@gmail.com 
Literature is an imitation and reflection of the reality that occurs in real life [3]. The events in literary works present most of the concepts of people's social life in the real world. The imitation of the absorption factor from the real-life situation contains a moral message for the literary work [5]. Indirectly, literary works have a role in evaluating real lives because of their ability to make readers aware of the problems in society's reality [8]. The reflection based on the up and down reality makes this poem suitable to analyze using Plato's mimesis theory. Plato argues that mimesis in the literature relates to the author's idea, but that is just in the scope of wishful thinking because it cannot produce an accurate imitation [3]. Mimesis is an approach to studying literary works that focuses on the relationship between literary works and reality outside of literary works. This approach assumes that literary works are an imitation of reality [6]. Therefore, an excellent literary work reflects based on the actual social portrait [7]. So, the approach using Plato's mimetic theory is a literary approach that focuses on reflection based on the relationship between literary works and realities outside the literary works [4].

\section{METHODOLOGY OF THE RESEARCH}

In his study, researchers used descriptive qualitative methods. Researchers will try to analyze the data and make a picture of the structure of Invictus. Qualitative methods involve collection and analysis. By applying this research method, the researcher describes and interprets the problem based on accurate data. This research is related to the poetry of William Ernest Henley

The strategic stages used are the stage of data provision, data analysis, and data analysis results. Through the data provision stage, the researcher observes the poetry in the overall meaning and relationship between the writer and his literary work. Then in data analysis, poetry is studied using a structural approach and Plato's theory of mimesis. Through a structural approach, we get the whole meaning of the poem. Furthermore, through Plato's mimesis theory, the researcher analyzes the relevance of poetry with social aspects in the real world.

\section{ANALYSIS RESULT}

\section{Poetic relation with his work}

William Ernest is an English famous poetry writer, literary critic of the late Victorian period. Since his childhood, William Ernest had Tuberculosis which attacked his bones. Tuberculosis has caused the amputation of his leg; however, the disease came back and attacked his other leg.

William through many treatments with the help of many experts. During his treatment, William began writing poetry about the experience of facing a bad situation with his illness. These poems were published into a book entitled The Book of Verses which was published in 1888. In his collection of poems, Invictus poetry work became the most popular. In the poem, William describes a difficult situation in his life. Through this poem, he refuses all outside influences or contexts outside of himself. No matter how complex the problem is, only he can save himself to get through it all. No one can dictate someone's life, because in fact, only we can control ourselves. Besides describing his current state, Invictus poetry gave William the spirit to keep going and fighting. 


\section{Structural Approach}

In the poem Invictus by William Ernest, there are four stanzas. This poem has a rhyme scheme with the pattern of A-B-A-B, C-D-C-D, E-F-E-F, and G-H-G-H. Each stanza has four lines, then each line consist of eight syllables. The rhyme scheme in the first stanza has a rhythmic patterned A-B-A-B. From all of the lines have eight syllables. When it is read, it also has the same stress and unstressed syllables. Then the second stanza also has four lines with an orderly rhythm pattern C-D-CD. Each line has eight syllables. The rhythm pattern on this stanza is dominant in the vocal sound "o", and while the third stanza has four lines with eight syllables in each line. The rhythm pattern is E-F-E-F with the dominant assonance in the vocal "e". This poem has a harmonious tone. Every line on each stanza has almost the same beat, which is it has eight syllables, and it has a regular rhythm pattern. The selection of vowels and consonants in make repetition is also considered in each stanza. Then, all of that creates a tone that sounds similar in rhythm when it is being read. That thing makes the reader more easily understand the contents of the poem through the sound.

In the first stanza, the writer uses connotative meaning, which means the writer's despair, gloom, and depression. The second stanza contains meaning which implies the hurt feeling and the worst condition. However, he gives an idea of his obstinacy. Although William tells the readers about how he felt so hurt and full of despair, he still does not give up, and he was never feeling despair. From the third stanza, we can find the description of conditions in which the writer reverses all the conditions of difficulty, pain, and gloom with his courage. Furthermore, in the last stanza, the author mentions how difficult and narrow the problems encountered we can go through. He believes that no matter how hard the problems we have, as long as we believe to be able to through it all and be challenging, surely, we can pass the problems. Moreover, he believes that who can control our lives is ourselves.

The author created the story. In this poem the poet, William Ernest tries to describe the condition when he is experiencing the gloomy and challenging condition of his life through the word 'night'. However, even though he felt his world was very bleak, he always believed in God, who always gave him strength, power, determination and willingness to up and never give up. He believes that the one who can help himself is himself.

From the reader's point of view approach, the value of life that can be taken is contained in every verse in the poem, which contains the struggle and spirit of life. Readers can take the meaning that no matter how painful or difficult the problems in life, we can provide encouragement and opportunity to succeed against all trials in our own lives. The readers will feel the surge of self-confidence that the author tries to instil in each stanza.

\section{Poetry as a reflection of reality}

In In Invictus poem, the poetic describes the complex condition which is reflected in endless darkness. However, in facing complex problems, he believed that God's power had a stronger role to give him courage. The author reflects grief and pain through a bleeding head and a shadow of seemingly endless hardships. However, with courage, he still stood tall through all the sadness and pain. Through his determination, he believed that no matter how hard the problems he has, as long as he believes to be able to through it, he can pass the problems. Because he believes that who can control his life is his self.

In real life, every complex condition will always turn into sunny conditions. For example, someone who successfully passed the exam of the University will find other problematic conditions in his struggle due to his study. As in the poem, the best way to deal with difficult conditions is to hold on to the power of God and one's abilities. In real life, someone closer to his God feels that difficult conditions are a test for a better life. So that they will be tougher and stronger in facing these conditions. In addition, a person who has excellent self-confidence also influences his ability to survive through demanding conditions. 


\section{CONCLUTION}

According to mimesis theory, literary works are depictions of real life. This theory is proven in William Ernest's poem Invictus. In his poetry, William Ernest reflects how someone should deal with challenging conditions in his life. By trusting in our own ability to stay strong through difficult times, we will be more motivated to survive through life's problems. In addition, the role of submitting to God is also an essential factor. Believing that there is no power more significant than the power of God can make a person more courageous through complex problems will make us braver. So, through this research, William Ernest's Invictus poem is a poem that gives inspiration and motivation to the readers live.

Through reflection on the complex struggles of life, Invictus poetry can positively impact its readers in providing motivation and high enthusiasm for life. This is related to the current situation of a pandemic. People need to increase self-confidence to get through this challenging condition. By reading Invictus poetry, readers can increase their motivation and have a big soul while through this pandemic.

\section{REFRENCES}

1. Cohen, E. Two Anticipations of Henley's "Invictus". Huntington Library Quarterly, 37(2), 191-196.doi:10.2307/3817033. (1974)

2. Diniejko, Dr Andrzej. "William Ernest Henley": A Biographical Sketch". The VictorianWeb, http://www.victorianweb.org/authors/henley/introduction.html

3. Teeuw, A. Sastra dan Ilmu Sastra: Pengantar Teori Sastra. Jakarta: Gramedia Pustaka Jaya. (1984)

4. Abrams, M.H. A Glossary of Literary Terms. Australia, Canada, Mexico, Singapore, and United Kingdom States: Heinle \& Heinle. (1999).

5. Wellek, Rene and Werren, Austin. Teori Kesusastraan. Jakarta: PT Grammedi. (1989).

6. Danyati, Ratna. Penerapan Mimesis Dalam Novel Empress Orchid Karya Anchee Min.

Seminar Nasional Inovasi dan Tren (SNIT). (2018).

7. Kiptyah, Maryatul. Cerpen "Perempuan Pala” Karya Azahli (Pendekatan Mimetik). Jurnal Pendidikan Bahasa, Sastra, dan Matematika, Vol. 1, No. 1. (2015).

8. Damono, Sapardi Djoko. Pedoman Penelitian Sosiologi Sastra. Jakarta. (2002).

9. Connell, John. W. E. Henley. London: Constable. (1949).

10. Henley, William Ernest. A book of verses. London: D. Nutt. (1888) 